\title{
Identification and documentation of wild plant species with ornamental potentials at Mount Prau, Central Java, Indonesia
}

\author{
Lianah Kuswanto $^{1}$ (D), Noor Amalia Chusna ${ }^{1}$ (D), Eko Purnomo ${ }^{1}$ (D), Krisantini² (D), Milya Urfa Ahmad AD $^{3}$ \\ ${ }^{1}$ Universitas Islam Negeri Walisongo Semarang, Department of Biology, Faculty of Science and Technology, Semarang, Indonesia. \\ ${ }^{2}$ IPB University, Department of Agronomy and Horticulture, Faculty of Agriculture, Bogor, Indonesia. \\ ${ }^{3}$ Universitas Sebelas Maret, Department of Biology, Faculty of Mathematics and Natural Sciences, Surakarta, Indonesia.
}

\begin{abstract}
Indonesia has diverse flora and fauna, and many species remain largely undiscovered. Documentation and identification of threatened wild ornamental species are increasingly difficult due to ongoing exploitation and land conversion. Mount Prau is one of the popular destinations in Central Java, Indonesia for tourism. Understanding plant biodiversity has enormous value for the economy, ecology, culture, science, and recreation. Our study is aimed to record the diversity and identify the flowering plant species in their native habitat at Mount Prau, Central Java, Indonesia. Our field surveys demonstrated that Mount Prau has abundant wild ornamental plants with wide diversity of taxa, growth habits, and forms. A total of 103 species representing 51 families and 95 genera are identified including trees, shrubs, herbs, and lianas. We also found that among the plant species found in Mount Prau, 24 have morphological characters suitable to be cultivated as ornamental flowers, and 12 as ornamental foliages, and 63 species are medicinal plants. The ornamental criteria of these species were based on the literature describing the morphological and unique characters of leaves and flowers that made them potential to be developed as ornamental plants. In this paper we have provided the current conservation status of the plant species identified and recommendations on their conservation. This study provides baseline data of species found in the Mount Prau areas, and this information could be helpful for further conservations efforts and initiatives. Keywords: documentation, identification, Mount Prau, ornamental, wild plants.
\end{abstract}

\section{Resumo \\ Identificação e documentação de espécies de plantas nativas com potencial ornamental no Monte Prau, Java Central, Indonésia}

A Indonésia possui flora e fauna diversificadas e muitas espécies permanecem em grande parte desconhecidas. A documentação e a identificação de espécies ornamentais nativas ameaçadas são cada vez mais difíceis devido à exploração contínua e à conversão de terras. O Monte Prau é um dos destinos turísticos populares de Java Central, na Indonésia. Compreender a biodiversidade vegetal tem um enorme valor para a economia, ecologia, cultura, ciência e recreação. Nosso estudo tem como objetivo registrar a diversidade e identificar as espécies de plantas com flores em seu habitat nativo no Monte Prau, Java Central, Indonésia. Nossos levantamentos de campo demonstraram que o Monte Prau possui abundantes plantas ornamentais silvestres com enorme diversidade de taxa, hábitos de crescimento e formas. Um total de 103 espécies representando 51 famílias e 95 gêneros são identificados, incluindo árvores, arbustos, ervas e cipós. Também foi identificado que dentre as espécies encontradas no Monte Prau, 24 destas espécies possuem caracteres morfológicos adequados para serem cultivadas como flores ornamentais e 12 como folhagens ornamentais. Neste artigo, é apresentado o estado de conservação atual das espécies de plantas identificadas e recomendações sobre sua conservação. Este estudo fornece dados de referência de espécies encontradas nas áreas do Monte Prau, e essas informações podem ser úteis para esforços e iniciativas de conservação adicionais.

Palavras-chave: documentação, identificação, Monte Prau, ornamentais, plantas silvestres.

\section{Introduction}

The loss of natural habitat mainly occurred due to land conversion to pastures, agriculture, and commercial development (Corlett, 2016), resulting in the extinction of various wild species of flora and fauna. Many plant species that were once abundant are now challenging to find in their natural habitat. Indonesia has the $8^{\text {th }}$ largest forest area globally at 120.6 million hectares or about $63 \%$ of the country's total land area. However, forest exploitation in

* Corresponding author: lianahk58@gmail.com

https://doi.org/10.1590/2447-536X.v28i1.2418

Received: July 13, 2021 | Accepted: Nov 04, 2021 | Available online: Nov 22, 2021

Licensed by CC BY 4.0 (https://creativecommons.org/licenses/by/4.0/)

Area Editor: Alejandro Salvio Escandon 
Indonesia was ranked the $3^{\text {rd }}$ highest in the world in 2018 (Pratama, 2020). Since 2015, around 30\% of conservation forests have been damaged due to forest encroachment by the community (Yustina et al., 2016). Deforestation has become more severe in the absence of an official assessment from the local government.

The issue of conservation has been the focus ofacademics, researchers, and environmentalists as the intensity of habitat exploitation has called for immediate conservation (Sharrock and Jackson, 2017). Studies on conservation so far have shown three trends. First, conservation is an effort to preserve natural resources (Saragih et al., 2019). Second, there are conservation models and approaches (Wiradimadja, 2018; Aviyana, 2016; Fa'atin and Sa'adah, 2018; Saroinsong and Kalangi, 2016); even religious and local traditions approaches have beencarried out as an effort to preserve the environment (Syukur and Qodim, 2016; Maula, 2017). Third, conservation of plants for uses as medicine (Wibisono and Azham, 2017). There has not been much conservation effort of wild ornamental plants in various regions from the trend of existing studies.

The distribution of ornamental plants can be associated with colonialism and globalization (Ciftcioglu et al., 2019). Paiva et al. (2020) show that consumers of flowers and ornamental plants in Brazil can spend $\mathrm{R} \$ 100.00$ to $\mathrm{R} \$ 200.00$ in one year. Ornamental plants allow humans to interact and modify the environment (Ilyas et al., 2021). In the ornamental plant industry, plant breeders continuously try to do selection and conventional crossings to modify the color of leaves, flowers and the aroma of plants. Various, advanced technologies have been used to create more diverse plant features for commercialization, such as the protoplast technology such as the protoplast technology, which currently being used to transform plants and produce new cultivars; the protoplast technology is popular within the international floriculture industry to meet the demand for ornamental plants (Naing et al., 2021).

Human activities, such as agriculture, aquaculture, modification of natural systems, climate change and extreme weather, mining and renewable energy, human intrusion and disturbance, and overuse of resources, threaten the existence of the native species, leading it to scarcity and even extinction (Cross et al., 2020). Among these activities, Cross et al. (2020) show that the most significant threats that place species at risk of extinction include urban development, agriculture, illegal hunting, and horticultural trade.

MountPrauisadormantvolcanolocated inDiengPlateau, Indonesia; it is one of the most popular hiking destinations in Central Java. Dieng itself is a popular holiday destination, with guesthouses, cafes, equipment shops, and tourist agencies. The native plants and flowers have been collected for private collections and commercial trading because of the increased tourist activities at Mount Prau (Daris and Wijaya, 2017). This condition is worsened by the occurrence of natural disasters and insufficient protection from the local government and policy makers. Extinction of species does have not only impacted the wild ornamental plants in this area, but also the other living things that depend on them.

This study aims to document the occurrence and to identify ornamental flora in various sites in Mount Prau, Indonesia. Specifically, this study was conducted to a) identify the wild plant species growing in the area, b) identify potential ornamental values of the flora of Mount Prau, and c) determine the factors that pose threats or causing the extinction of wild ornamental plants in the area. The information from this survey will complement the studies on ornamental flora conservation, particularly at the Mount Prau region. We also provided recommendations for further research on ornamental flora documentation by doing this study.

\section{Material and Methods}

Observations, records, and documentation in the form of notes and photos were taken in the forest area of Mount Prau ( $\left.7^{\circ} 11^{\prime} 13^{\prime \prime} \mathrm{S} 109^{\circ} 55^{\prime} 22^{\prime \prime} \mathrm{E}\right)$. We conducted five traveling routes covering four districts at Mount Prau, i.e., Kendal $\left(07^{\circ}\right.$ 08' 53.69892'LS, 109 56' 20.79037'BT), Temanggung $\left(110^{\circ} 23.1104630\right.$ 'BT, $\left.7^{\circ} 14.73235^{\prime \prime L S}\right)$, Banjarnegara (07 11' 12.2638631'"LS, 109 55'04.60210"BT), Kejajar Wonosobo (07 ${ }^{\circ} 11^{\prime} 12.97856^{\prime \prime} \mathrm{LS}, 109^{\circ} 55^{\prime} 22.37948^{\prime}$ 'BT) and at the top of Mount Prau $\left(7^{\circ} 11^{\prime} 13^{\prime \prime} \mathrm{S}, 109^{\circ} 55^{\prime} 22^{\prime \prime} \mathrm{E}\right)$ (Figure 1). 


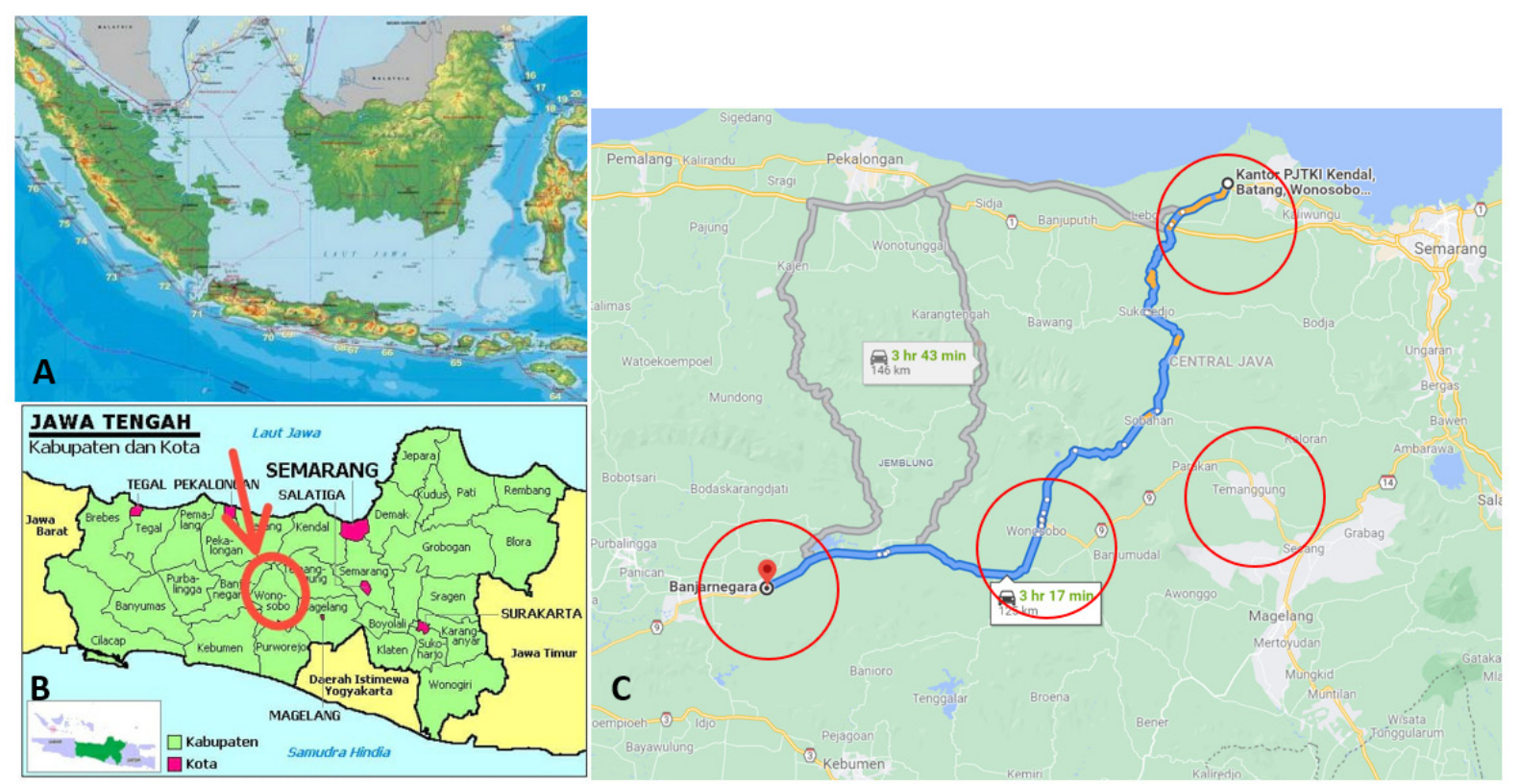

Figure 1. Research site map showing (A) Indonesian map; (B) Central Java location map; (C) Map of research locations Kendal, Temanggung, Banjarnegara and Kejajar Wonososbo

The total area of study covered $16.5 \mathrm{~km} 2$ with altitudes ranging from $900-2500 \mathrm{~m}$ above the sea level (a.s.1.). The climate is type hot and humid, with a dry season with rather severe drought between February and July, and a rainy season between October and December (BMKG, 2020). The average annual temperature is $27.1^{\circ} \mathrm{C}$, with annual rainfall of $1,442 \mathrm{~mm}$ and annual average relative humidity of $76 \%$ (BMKG, 2020).

All specimen samples were photographed and collected, then identified for their ornamental values and potential use as flowering potted plants, ornamental foliage, and small trees. The ornamental values are based on the plants' unique and attractive color, texture, shape, pattern of the leaf, flower, and stem described in Table 1 (Stumpf et al., 2009; Sousa and Versieux, 2020). Mature leaves were selected for morphological evaluation. Flower characteristics were selected from plants that have flowered at the full bloom stage. Based on morphological data, identification was conducted according to the description in the flora of IndoChina, British India, China, and the Malay Peninsula, and scientific publications, and confirmed by a taxonomist from Herbarium Bogoriense for the identification of the specimens. The collected specimens that have not been recorded in the Herbarium were reported.

Table 1. Morphological and type of growth evaluation of the ornamental species of Mount Prau, Central Java, Indonesia, with the potential use in ornamental flower industry*

\begin{tabular}{|c|c|}
\hline PARAMETER & CHARACTERS \\
\hline Growth habit & Tree, shrub, herbs, vines, epiphytic \\
\hline Life cycle & Annuals, perennials \\
\hline Plant shape & $\begin{array}{l}\text { Vertical (height }>\text { canopy diameter), horizontal } \\
\text { (canopy }>\text { height), balanced } \\
\text { (diameter of canopy similar to plant height), others. }\end{array}$ \\
\hline Symmetry of the branches & Symmetrical, asymmetrical (i.e. branches grow in random directions). \\
\hline Colour of leaf, flower, capsule, bark & Visual determination \\
\hline Texture of leaf, flower, capsule, stem & Smooth/rough, hairy/glabrous \\
\hline Other distinct and unique physical characters & Visual and spot determination \\
\hline
\end{tabular}

*Adapted from Stumpf et al., 2009; Sousa and Versieux, 2020 


\section{Results and Discussion}

\section{Diversity of plant species at Mount Prau}

Field exploration of wild vegetation in Mount Prau has demonstrated a wide floristic diversity. A total of 112 individuals representing 103 species and consisting of 51 families and 95 genera of flowering and nonflowering plants were identified. The plant families with ornamental values include Asteraceae (19 species), Lamiaceae (5 species), Achantecaeae (5 species), Solanaceae (5 species), Euphorbiaceae (2 species) (Figure 2), and Pteridophytes (12 species). Based on the morphological characters of these species (described by Stumpf et al., 2009; Sousa and Versieux, 2020;
Table 1), 12 species have potentials to be developed as ornamental foliage (Table 2), and 24 species as flowering ornamentals (Table 3). Additionally, three endemic and rare species were found, Anaphalis javanica (Javanese edelweiss, Figure $3 \mathrm{~B}$ and Figure 4) (Whitten et al., 1992), Dodonaea viscosa (Figure 5), and Tetrastigma glabratum (Figure 6) (Lianah, 2014). The species in our study have different growth habits, i.e., herbs, shrubs, trees, creeping and climbing lianas, and epiphytes (Table 2 and 3). Twenty-eight species are annual herbs (A.H.), 18 are perennial herbs (P.H.), 6 are tree (T.), 7 are ferns (Fn.), and, 5 are fern epiphytes (Fn.Ep.), 31 are shrubs (S/ shrub), six each are climber ( $\mathrm{Cl}$.) and 2 are rhizome herb (Rh.H.) and bulb herb (B.H.), respectively (Figure 2).

Table 2. Species that have potentials to be domesticated as foliage ornamentals

\begin{tabular}{|c|c|c|c|}
\hline NO & BOTANICAL NAME & FAMILY & Notes \\
\hline 1 & Alocasia portei Schott & Araceae & $\begin{array}{l}\text { Herbaceous perennial; } \\
\text { attractive leaf shape }\end{array}$ \\
\hline 2 & Alpinia zerumbet B.L.Burtt and R.M.Sm & Zingiberaceae & Perennials; attractive leaf color pattern \\
\hline 3 & Begonia rubra Blume Presl. & Begoniaceae & $\begin{array}{l}\text { Herbaceous perennial; } \\
\text { unique spotted leaves }\end{array}$ \\
\hline 4 & Davallia solida G. Forst & Davalliaceae & $\begin{array}{l}\text { Epiphytic fern; attractive leaf shape; also use- } \\
\text { ful as medicinal plant }\end{array}$ \\
\hline 5 & Dracaena fragrans (L.) Ker Gawl. & Asparagaceae & Perennials; attractive leaf color pattern \\
\hline 6 & Hemigraphis colorata W. Bull & Acanthaceae & Climbers; deep-purple color leaves \\
\hline 7 & Monophyllaea horsfieldii R. Brown & Gesneriaceae & $\begin{array}{l}\text { Shrubs; unique plant and leaf shape; the plant } \\
\text { only has one large deep-vein leaf }\end{array}$ \\
\hline 8 & Nephrolepis cordifolia (L) C. & Devalliaceae & Fern; attractive leaf shape \\
\hline 9 & Pilea cadierei Gagnep. \& Guillaumin & Urticacae & $\begin{array}{l}\text { Herbaceaous annuals; } \\
\text { attractive leaf color pattern }\end{array}$ \\
\hline 10 & Pteris vittate $\mathrm{L}$. & Pteridaceae & Fern; attractive leaf shape \\
\hline 11 & Schismatoglottis acuminatissima Schott & Araceae & $\begin{array}{l}\text { Herbaceous annuals; } \\
\text { attractive leaf color pattern }\end{array}$ \\
\hline 12 & Senecio cineraria $\mathrm{L}$. & Asteraceae & $\begin{array}{l}\text { Herbaceous annuals; attractive color, suc- } \\
\text { culent }\end{array}$ \\
\hline
\end{tabular}


Table 3. Species that have potentials to be domesticated as flowering ornamentals.

\begin{tabular}{|c|c|c|c|}
\hline NO & BOTANICAL NAME & FAMILY & Notes \\
\hline 1 & Aechmea caudate Lindm. & Bromeliaceae & Herbaceaous perennial \\
\hline 2 & Callistephus chinensis L. Nees & Asteraceae & Annual herbaceous \\
\hline 3 & Calliandra tetragona Benth. & Leguminosae & Shrub \\
\hline 4 & Cestrum nocturnum L. & Solanaceae & Shrubs, night flowering, scented \\
\hline 5 & Chrysanthemum sp. L. & Asteraceae & Annual herbaceous \\
\hline 6 & Chrysanthemum indicum L. & Asteraceae & Annual herbaceous \\
\hline 7 & Crinum latifolium $\mathrm{L}$. & Amaryllidaeceae & Bulbous herbs \\
\hline 8 & Gomphrena globosa L. & Amaranthaceae & $\begin{array}{c}\text { Annuals; also used as medicinal plant by the } \\
\text { local community }\end{array}$ \\
\hline 9 & Hibiscus sp. L. & Malvaceae & Shrubs \\
\hline 10 & Ixora javanica (Blume) DC. & Rubiaceae & Shrubs \\
\hline 11 & Kalanchoe laciniata (L) DC. & Crassulaceae & Herbaceaous perennial \\
\hline 12 & Neomarica longifolia & Iridaceae & Rhizomatous herbaceous \\
\hline 13 & Pachystachys coccinea Nees & Acanthaceae & Shrubs \\
\hline 14 & Rheum officinale L. & Polygonaceae & Annual Herb \\
\hline 15 & Rhodendron sp. L. & Ericaceae & Shrubs \\
\hline 16 & Rhododendron javanicum $\mathrm{L}$. & Erieaccae & Shrubs, endemic species \\
\hline 17 & Rosa chinensis Jacq. & Rosaceae & Shrubs \\
\hline 18 & Ruellia tuberosa L. & Achantaceae & $\begin{array}{l}\text { Shrubs, also used as medicinal plant by the } \\
\text { local community }\end{array}$ \\
\hline 19 & Salvia coccinea $\mathrm{L}$. & Lamiaceae & Perennial herbaceous \\
\hline 20 & Stachytarpheta cayennensis (Rich.) Vahl & Verbenaceae & Shrub \\
\hline 21 & Symphyotrichum ericoides L. (G.L. Nesom) & Asteraceae & $\begin{array}{l}\text { Shrubs, also used as medicinal plant by the } \\
\text { local community }\end{array}$ \\
\hline 22 & Torenia fournieri Linden ex E. Fourn. & Linderniaceae & Annual herbaceous \\
\hline 23 & Tibouchina semidecandra Cong & Melastomataceae & Shrubs \\
\hline 24 & Vinca rosea $\mathrm{L}$. & Apocynaceae & Herbaceaous perennial \\
\hline
\end{tabular}

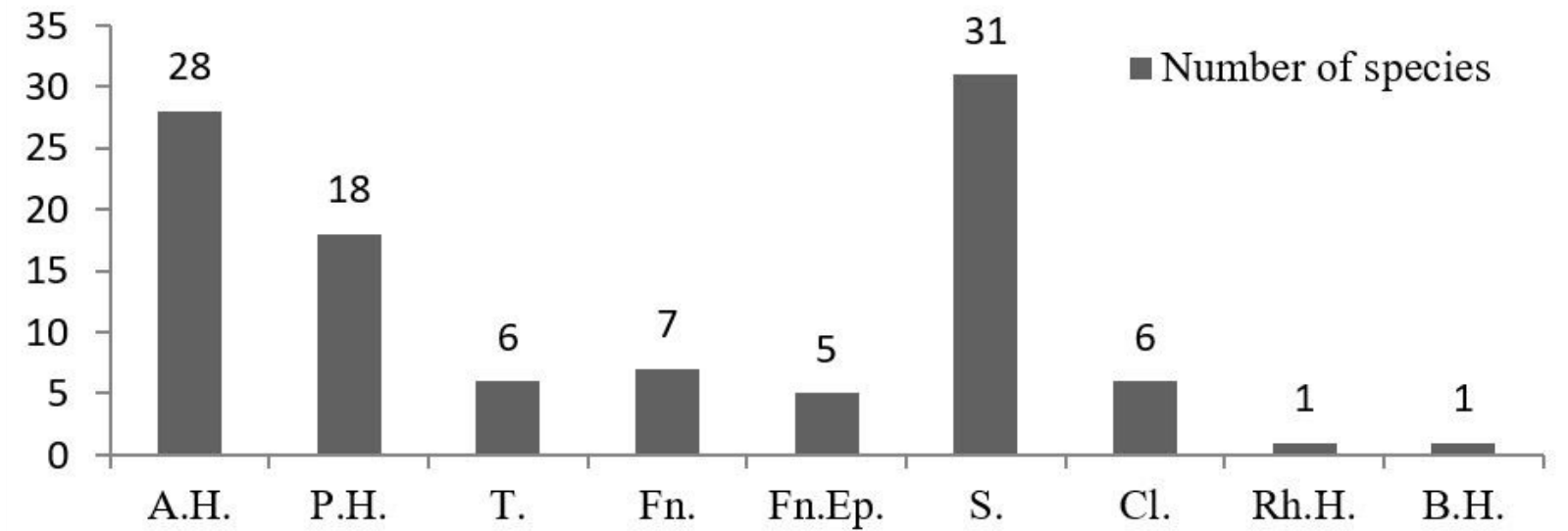

Figure 2. Distribution of species based on their growth habit: annuals (A.H.), perennials (P.H.), tree (T.), fern (Fn.), fern epiphyte (Fn.Ep.), shrubs (S), climber (Cl.), rhizome (Rh. H.) and bulb (B.H.) 
The Rare Species Found in Mount Prau

Figure 3 shows the endemic plants of Mount Prau at an altitude of 2.500 m.a.s.l. i.e. Passiflora coccine (Figure 3A), Anaphalis javanica (Figure 3B and 4), Vaccinium varingiaefolium (Figure 3C), Allmania nodiflora (Figure 3D), Rhododendron javanicum (Figure 3E), Hypericum leschenaultia (Figure 3F), Sedum album (Figure 3G), and Quisqualis indica (Figure 3H). These species have bright, showy colorsin their flowers, making them potential candidates to be domesticated as ornamental plants. Among these, tourists frequently hunt for $A$. javanica (Figure 3B and 4).
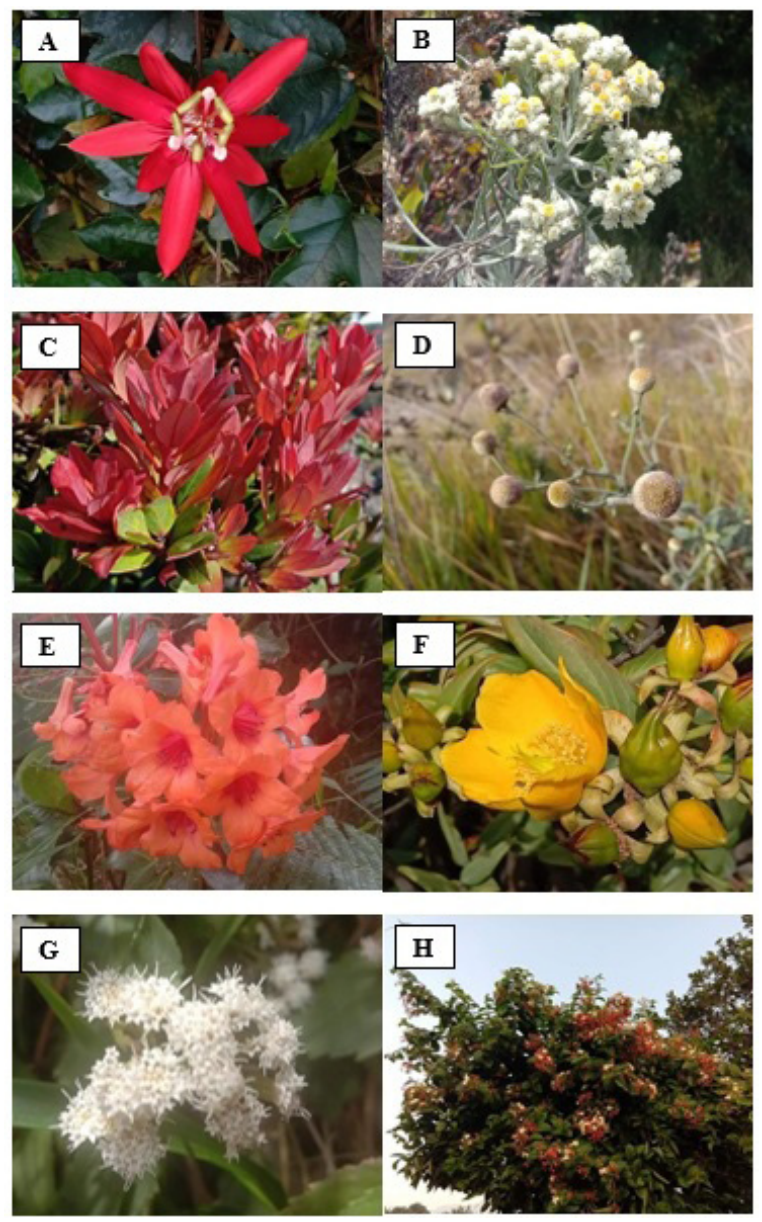

Figure 3. Endemic plants of Mount Prau. (A) Passiflora coccinea; (B) Anaphalis javanica; (C) Vaccinium varingiaefolium; (D) Almanicanodiflora; (E) Rhododendron javanicum;

(F) Hypericumleschenaultii; (G) Sedum album; and (H) Quisqualis indica.

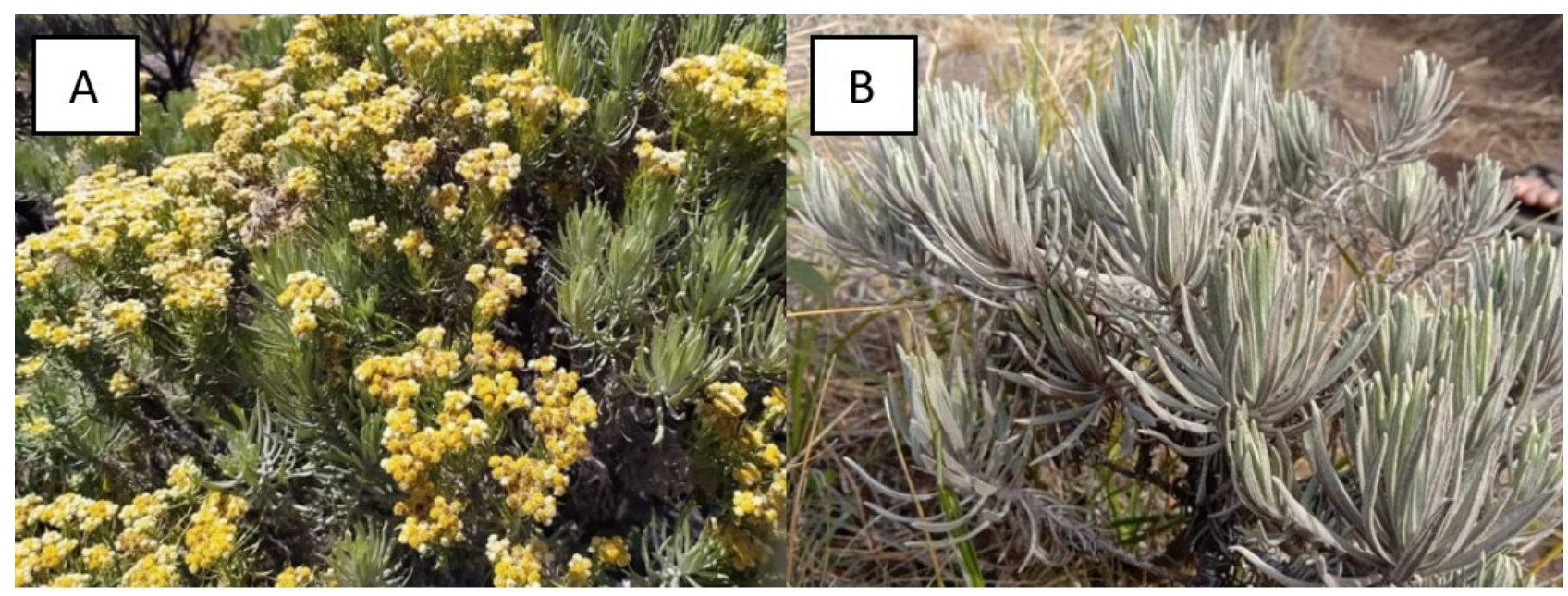

Figure 4. Flower (A) and leaf morphology of Anaphalis javanica (Reinw. ex Bl.) Sch. Bip (Javanese Edelweiss). 
Anaphalis javanica is a flowering species endemic to Indonesia and known as 'Javanese edelweiss.' Whitens et al. (1992) reported that $A$. javanica had been found to grow in the mountainous regions of Java, Sumatra, Sulawesi, and Lombok. Anaphilis javanica that we found at mount Prau are generally \pm 1 meters in height at an altitude of 2,000 m.a.s.l. Allmania nodiflora (Figure 3D) are also known as eternal flowers because their petals are long-lasting and can last up to 10 years. The long lasting flowers of $A$. nodiflora and A. javanica is an important character for potential use as cut flowers. The flowers have been frequently collected as a souvenir by the people climbing Mount Prau. According to Setiyo and Haddy (2019), Anaphalis javanica has important roles in the mountain ecosystem; it is one of the essential food sources for insects, plant host for Myophonus glaucinusor the Javan whistling thrush, and growing in groups they can prevent landslides and erosion. Anaphalis javanica is a pioneer species in young volcanic soil and can maintain its survival on barren earth by forming mycorrhizae, thereby expanding the area of root coverage to look for nutrients (Ade et al., 2019).

Anaphalis javanica usually bears flowers between April and August. Currently, there is an existing cultivation group responsible for propagating this species. Anaphalis javanica has been protected in the Regulation of the Minister of Environment and Forestry Number P.92 (2018) on Protected Types of Plants and Animals. However, in the Mount Prau area, this plant is not being propagated yet. In Indonesia, collecting native plants from their natural habitat is commonly done; therefore, conservation of this species isurgent in this location. It is also necessary to issue local and regional regulations to protect this species.

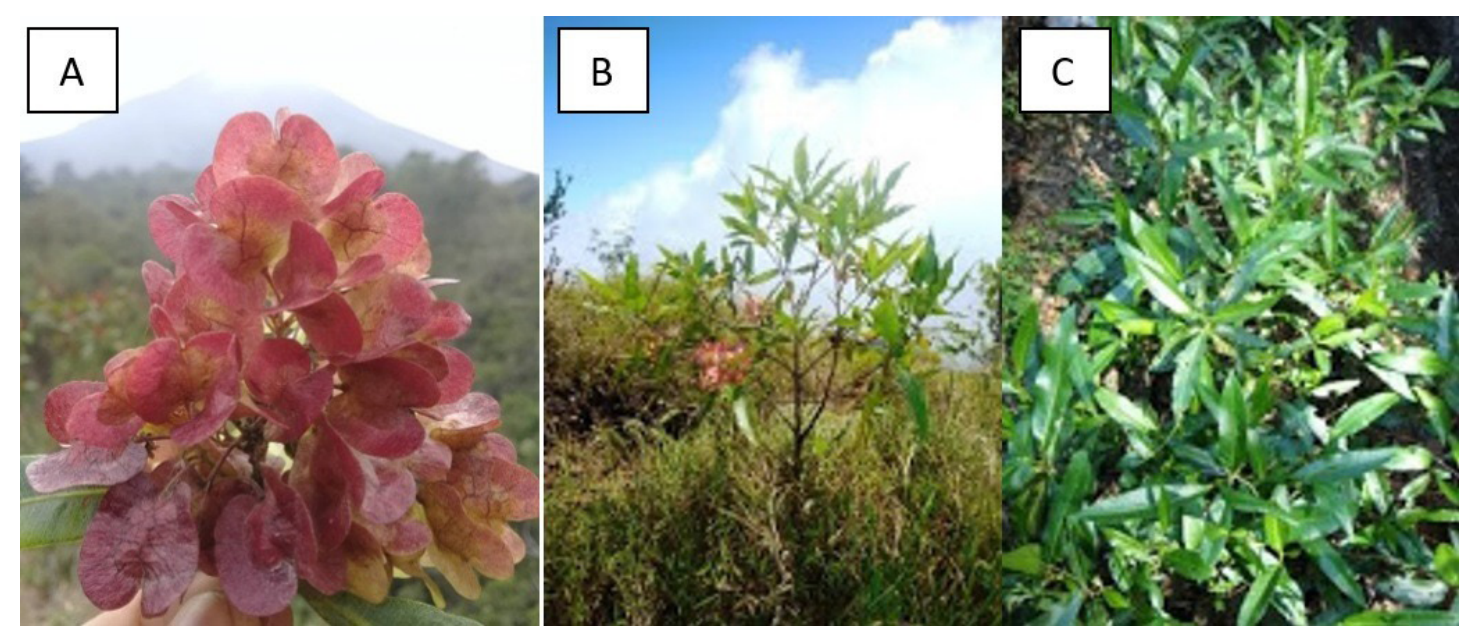

Figure 5. Morphology of Dodonaea viscosa (A) Capsules; (B) Tree; (C) Leaves.

Another unique endemic plant in Mount Prau is Dodonaea viscosa (Figures 5A, B, C), locally known as 'tengsek tree' or 'dolu'. Dodonaea viscosa is found at an altitude of 1.300 m.a.s.l. Dodonaea viscosa flowers are inconspicuous and have no petals, the colorful parts are actually capsules. Fertilized capsules can take up to 11 months to mature, and over this time, the capsules will change color from a green or cream color to a brilliant red (Hidayat and Suhendri, 2020). The soft colorof the capsules (Figure 5A) makes them suitable as flowering shrubs or small trees for landscapes. People consider $D$. viscoca as lucky trees, making it frequently hunted. Dodonaea viscosa is a woody perennial, and most of the plant population that we discovered at Mount Prau is 1-7 $\mathrm{m}$ in height. The local people used Dodonae viscosa stem as a material for making the sheath of the keris, a traditional Javanese weapon with unique shapes. The leaves are single-spreading, slightly variable, oval to lancet, green, pinnate leaf bone (Pongtiku, 2016) with a thin, supple, shiny, or oily look. Dolu leaves are commonly used in traditional medicine and raw materials to make keris by the local people so they are increasingly hard to find, while no cultivation or propagation has been conducted to preserve them. It is imperative to propagate this species either in-situ or ex-situ and to be protected from illegal collection.

In addition to Dodonaea viscosa, two endemic species in Mount Prau have been identified, Tetrastigma glabratum (Figure 6A) and Symphyotrichum ericoides (Figure 6B and C), also known as daisy or aster. Tetrastigma glabratum (local name: oyod gang, walikadep) is a liana found climbing on tall trees in the Mount Prau forest at an altitude of 1300 m.a.s.l. Tetrastigma glabratum grows wild at Mount Prau and the surrounding areas, especially in Blumah Village (Lianah, 2014). The local people at the villages around the area have been using the liquid exudates from $T$. glabratum to children's appetite, to treat coughing and to maintain health in general (Lianah, 2014). The parts of the plants that have been collected are the stems with large diameters, i.e., from the older trees. Tetrastigma glabratum is ahost for Rafflesia, the largest flowering species in the world. Therefore, to conserve both the host and Rafflesia, there is an urgent need to propagate them either in-situ or ex-situ. Tetrastigma glabratum also needs to be protected legally. 


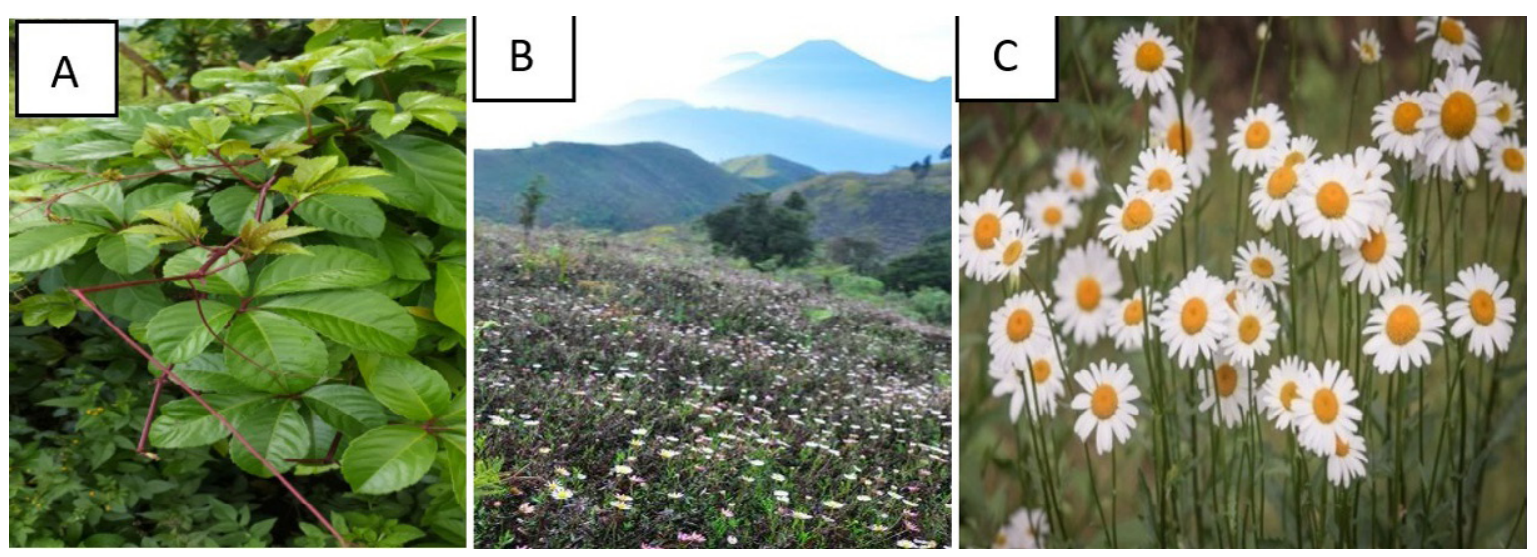

Figure 6. Other unique endemic plants in Mount Prau. (A) Tetrastigma glabratum Blume. Planch; (B) and (C) Symphyotrichum ericoides L. (G.L. Nesom)

At the time of our exploration, $S$. ericoides were abundant in Mount Prau; they were found to grow on dry and rocky soils. The survey was conducted during the dry season, and there was no rain for about 3 months (BMKG, 2020). Symphyotrichum ericoides is widely known as heath aster. Symphyotrichum ericoides are perennials, and most of the plants that we found are $50-70 \mathrm{~cm}$ tall. Their flowers are composite with white ray flowers in contrast to their yellow disk flowers at the centers. The inflorescence diameter is about 10 $\mathrm{mm}$ across. In our opinion, for now, there is no urgent need to call for the legal protection of this species. Additionally, it is not over-exploited in the area. Being widely distributed in the area, this makes these daisies better suited for domestication.

The dynamic floriculture industry is constantly looking for new products with more diverse physical appearances, textures, and patterns (Krisantini et al., 2014). Therefore, new species with unique shapes, colors, and patterns of flowers, leaves, or stems are always wanted to be introduced to the floricultural market. Propagation and domestication of unique and beautiful species need integrated research and development efforts and require strong collaboration between research institutions, universities, and the local government. In developing new hybrids, it is vital to have a vast collection of species (Ghimiray and Vernooy, 2017). Therefore, it is very important to protect the species diversity in their natural habit. The floriculture industry and landscaping business in Indonesia has been the source of income for the locals, and there has been increasing awareness to build environmentally friendly human habitats. The flowering species that we have found in our study could be helpful for the local people and add new products to the Indonesian flower and ornamental plant market.

Conservation efforts should be carried out considering specific and contextual driving factors, including integration of nature conservation and forest management (Henri et al., 2018). In line with that, to assist in formulating conservation planning both in-situ and ex-situ, a priority list of species is needed. This priority list can further help achieve the Global Strategy for Plant Conservation 20112020 (Cahyaningsih et al., 2021).

\section{Factors threatening the extinction of ornamental} wild plants

We recorded that natural disasters are unavoidable conditions that cause environmental damage, thereby affecting various rare plant species that live naturally. Mount Prau is vulnerable to natural disasters such as heavy rain, landslide, volcano eruption, making its natural vegetation prone to destruction. Ignorance of plant uses and other benefits make humans exploit rare species to extinction; tourist visits to Mount Prau had disrupted the natural growth of wild species. Illegal and indiscriminate harvesting of plants has broken the chain of native plant growth. During the pandemic in 2020, the number of visitors to Mount Prau has been limited to only 1,500 people per day.

Worldwide, deforestation and forest degradation affect biodiversity and practices and become a driving factor for biodiversity loss caused by exploitation practices (Tsujino et al., 2016). In the Mount Prau region, the main threat is the overexploitation of native plants by visitors, climbers and tourists. The impact of the extinction of a species will result in the extinction of species relying on them. It will harm the balance of the ecosystem and eventually on humans.

\section{Conclusions}

Wild plant species in Mount Prau should receive more protection from various threats of extinction, and the high intensity of tourist visits to Mount Prau is one of the main factors that need to be managed. The wild plant species with potential ornamental values are Anaphylis javanica, Dodonaea viscosa, and Symphyotrichum ericoides. We strongly suggest the local government enforce the regulations to protect these species from extinction. Future research efforts should be directed into studying reproductive biology, propagation, and optimal culture of these species and develop their potentials as ornamental plants. 


\section{Acknowledgments}

The author would like to thank the dean of the Faculty of Science and Technology, Universitas Islam Negeri Walisongo Semarang, who has helped fund the writing of this article. The authors thank the head of Dieng Wetan village, Banjarnegara district, Mr. Ali Khasan, the head of Blumah village, Kendal district, Mr. Yazid and Mr. Syaifudin. Dewi Sura Aprillia, Nisa, and Desty, students of U.I.N. Walisongo Semarang, who provided help and assistance during the research and exploration; Yusuf Iskandar and Yusuf Taufiqul Khafid as the photographer, Mr. Ruspandi, botanist (semi-retired) from the Herbarium Bogoriense who have helped with the identification of plant species, and the manager of the Telaga Warna Dieng Wonosobo tourist park, Mr. Agus Purnomo, who has provided information on the rare plant species.

\section{Author Contibution}

LK: research orientation, survey and monitoring the entire activities, preparation of the manuscript; NAC.: survey, suggestions, recording, documentation; EP: survey, suggestions, documentation; K: idea, research orientation, method development, preparation of the manuscript; MUA: survey, preparation of the manuscript.

\section{References}

ADE., F.Y.; HAKIM, L.; ARUMINGTYAS, E.L.; AZRIANINGSIH, R. The Detection of Anaphalis spp. genetic diversity based on molecular character (using ITS, E.T.S., and EST-SSR markers). International Journal on Advanced Science, Engineering and Information Technology, v.9, n.5, p.1695-1702, 2019. https://doi. org/10.18517/ijaseit.9.5.9597

AVIYANA, V.D. Pink beach ecotourism potential in the context of nature conservation in East Lombok Regency. Journal of Green Growth and Environmental Management, v.5, n.2, p.41-56, 2016. https://doi. org/10.21009/jgg.052.05

BMKG. 2020. Available at: <https://www.iklimjateng. info $>$ Accessed on: Nov 9th 2021.

CAHYANINGSIH, R.; BREHM, J.M.; MAXTED, N. Setting the priority medicinal plants for conservation in Indonesia. Genetic Resources and Crop Evolution, v.68, n.5, p.2019-2050, 2021. https://doi.org/10.1007/s10722021-01115-6

CIFTCIOGLU, G.C.; EBEDI, S.; ABAK, K. Evaluation of the relationship between ornamental plants-based ecosystem services and human wellbeing: A case study from Lefke Region of North Cyprus. Ecological Indicators, v.102, p.278-288, 2019. https://doi.org/10.1016/j. ecolind.2019.02.048
CORLETT, R.T. Plant diversity in a changing world: status, trends, and conservation needs. Plant Diversity, v.38, p.1016. 2016. https://doi.org/10.1016/j.pld.2016.01.001

CROSS, A.T.; KRUEGER, T.A.; GONELLA, P.M.; ROBINSON, A.S.; FLEISCHMANN, A.S. Conservation of carnivorous plants in the age of extinction. Global Ecology and Conservation, v.24, p.e01272, 2020. https:// doi.org/10.1016/j.gecco.2020.e01272

DARIS, R.M.; WIJAYA, H.B. Pengaruh pariwisata pendakian gunung prau terhadap ekonomi masyarakat Desa Patak Banteng Kabupaten Wonosobo. Teknik PWK (Perencanaan Wilayah Kota), v.6, n.2, p.125-130, 2017.

FA'ATIN, S.; SA'ADAH, N. Nature conservation: the activities of the community caring for the forest (PMH) within the framework of the living Qur'an in Kudus Regency. Jurnal Ilmu Ushuluddin, v.17, n.1, p.51-76, 2018. https://doi.org/10.30631/tjd.v17i1.61

GHIMIRAY, M.; VERNOOY, R. The importance and challenges of crop germplasm interdependence: the case of Bhutan. Food Security, v.9, n.2, p.301-310, 2017. https:// doi.org/10.1007/s12571-017-0647-5

HENRI, H.; HAKIM L.; BATORO, J. Local wisdom of the community as an effort to conserve the pelawan forest in Central Bangka Regency, Bangka Belitung. Jurnal Ilmu Lingkungan, v.16, n.1, p.49-57, 2018. https://doi. org/10.14710/jil.16.1.49-57

HIDAYAT, I.W.; SUHENDRI, Y. Observation series of flowering and fruiting phenology of Mischocarpus pentapetalus (Roxb.) Radlk. (Sapindaceae) in Cibodas Botanic Gardens, 2014-2018. Buletin Kebun Raya, v.23, n.3, 196-209, 2020. https://doi.org/10.14203/bkr.v23i3.658

ILYAS, M.; LIU, Y.Y.; SHAH, S.; ALI, A.; KHAN, A.H.; ZAMAN, F.; YUCUI, Z.; SAUD, S.; ADNAN, M.; AHMED, N.; ALI, B.; FAHAD, S.; WANG, Y.J. Adaptation of functional traits and their plasticity of three ornamental trees growing in the urban environment. Scientia Horticulturae, v.286, p.110248, 2021. https://doi. org/10.1016/j.scienta.2021.110248

KRISANTINI; AISYAH, S.I.; SUKMA, D. Budidaya Tanaman Hias Pot. DeePublish, p.5-7. 2014.

LIANAH, L. Description, and ecology of Indonesian species Tetrastigma glabratum (Blume) Planch, a host of Rafflesiaceae. Journal of Tropical Crop Science, v.1, n.2, p.1-3, 2014. https://doi.org/10.29244/jtcs.1.2.1-3

MAULA, B.S. Insight of the Qur'an on nature conservation. MAGHZA: Journal of the Science of the Qur'an and Tafsir, v.2, n.2, p.57-68, 2017. https://doi.org/10.24090/ maghza.v2i2.1569 
MINISTER OF ENVIRONMENT AND FORESTRY OF THE REPUBLIC OF INDONESIA. Regulation of the Minister of Environment and Forestry Number P.92/MENLHK/SETJEN/KUM.1/8/2018 concerning Amendments to the Regulation of the Minister of Environment and Forestry Number P.20/MENLHK/ SETJEN/KUM.1/6/2018. [Concerning Plant Types and Protected Animals.] Ministry of Environment and Forestry of the Republic of Indonesia, 2018.

NAING, A.H.; ADEDEJI, O.S.; K.I.M., C.K. Protoplast technology in ornamental plants: Current progress and potential applications on genetic improvement. Scientia Horticulturae, v.283, p.110043, 2021. https://doi. org/10.1016/j.scienta.2021.110043

PAIVA, P.D.O; REIS, M.V.D.; SANT'ANA, G.S.; BONIFÁCIO, F.D.L.; GUIMARÃES, P.H.S. Flower and ornamental plant consumers profile and behavior. Ornamental Horticulture, v.26, n.3, p.333-345, 2020. https://doi.org/10.1590/2447-536X.V26I3.2158

PONGTIKU, A. Dinas Kesehatan Provinsi Papua, 2016.

PRATAMA, A.R. Menghadapi bencana ekologis dan menggugat konservasi hutan Kalimantan Timur. LSP Jurnal Ilmiah Dosen, v.39, n.2, p.144-160, 2020.

SARAGIH, D.P.; YUSUF, A.P.; ADAM, A.F. The supervisory function of the Natural Resources Conservation Center (BKSDA) in conserving natural resources. Musamus Journal of Public Administration, v.1, n.2, p.25-31, 2019. https://doi.org/10.35724/mjpa. v1i2.1987

SAROINSONG, F.B.; KALANGI, J.I. [Natural resource management techniques for conservation in residential areas.] ABDIMAS: Jurnal Pengabdian kepada Masyarakat, v.9, n.01, 2018. https://doi.org/10.36412/ abdimas.v9i01.579

SHARROCK, S.; JACKSON, P.W. Plant conservation, and the sustainable development goals: A policy paper prepared for the global partnership for plant conservation. Annals of the Missouri Botanical Garden, v.102, p.2, n.290-302, 2017. https://doi.org/10.3417/D-16-00004A

SETIYO UTOMO, A.B.; HEDDY, Y.B. [Ethnobotany of Edelweiss (Anaphalis spp.) in Ngadas Village, Bromo Tengger Semeru National Park.] Jurnal Produksi Tanaman, v.6, n.8, p.1684-1654, 2019.
SOUSA, V.F.; VERSIEUX, L.M. Ornamental potential of Restinga plants from Rio Grande do Norte: towards a sustainable landscaping. Plant Now, v.1, p.28-37, 2020.

STUMPF, E.T.; ROMATO, C.M.; BARBIERI, R.L.; HIEDEN, G.; FISCHER, S.Z.; CORREA, L.B. Características ornamentais de plantas do Bioma Pampa. Revista Brasileira de Horticultura Ornamental, v.15, n.1, p. 49-62, 2009.

SYUKUR, A.; QODIM, H. Islam, local traditions, and nature conservation: A case study in Dukuh Village, Garut Regency. Kalam, v.10, n.1, p.141-168, 2016. https://doi. org/10.24042/klm.v10i1.339

TSUJINO, R.; YUMOTO, T.; KITAMURA, S.; DJAMALUDDIN, I.; DARNAEDI, D. History of forest loss and degradation in Indonesia. Land Use Policy, v.57, p.335-347, 2016. https://doi.org/10.1016/j. landusepol.2016.05.034

WHITTEN, T.; WHITTEN, J.; CUBBIT, G. Wild Indonesia: The wildlife and scenery of the Indonesian Archipelago. United Kingdom: New Holland, 1992. p.208.

WIBISONO, Y.; AZHAM, Z. Inventory of medicinal plant species in the conservation plot of medicinal plants in KHDTK Samboja, Samboja District, Kutai Kartanegara Regency. Agrifor: Journal of Agricultural and Forestry Sciences, v.16, n.1, p.125-140, 2017. https://doi. org/10.31293/af.v16i1.2599

WINSLOW, R.S. A native forb for conservation use in Montana and Wyoming. Plant Materials Technical Note MT-108. Bridger: United States Department of Agriculture, 2015. p.5.

WIRADIMADJA, A. Local wisdom of the people of Kampung Naga as nature conservation in preserving Sundanese culture. Journal of Sociology of Humanist Education, v.3, n.1, p.1-8, 2018. http://dx.doi. org/10.17977/um021v3i1p1-8

YUSTINA, Y.; DARMADI, D.; IRIANTI, M.; DAHNILSYAH, D. The perspectives of local wisdom in conservation and biodiversity management of fish species at Rangau River, Riau Province, Indonesia. International Journal of Educational Best Practices, v.2, n.2, p.48-54, 2016. http://dx.doi.org/10.31258/ijebp.v2n2.p48-54 